\title{
The syntax of subjects in the acquisition of Spanish and Catalan
}

AURORA BEL

Abstract

In the acquisition literature, the phenomenon of early null subjects has received a lot of attention over the past two decades, especially in the case of non null subject languages. A number of different proposals have been advanced by Hyams (1986, 1994, 1996), Valian (1991) and Rizzi (1994), among others. Based on longitudinal data from three Spanish-speaking children and three Catalan-speaking children aged 1;7-2;8, I investigate null and overt subjects in the acquisition of two null subject languages, Spanish and Catalan, and argue in favor of an analysis within the Continuity Hypothesis. Briefly, in the area of the syntax of subjects, this hypothesis predicts an early convergence between child and adult grammars. The analysis addresses the question of finiteness, i.e., whether there are differences in the behavior of subjects between finite and non-finite constructions. The findings allow us to propose that early grammars of Spanish and Catalan have Tense, except for non-finite constructions. For these non-finite structures I propose an extension of Rizzi's Truncation Hypothesis. The theoretical consequences derived from the analysis are extended to other phenomena, such as pronominal subjects and the relative position of subjects, and other languages, such as English, and confirm the above mentioned convergence.

The phenomenon of early null subjects in children's speech has generated much research over the past two decades, especially in the case of non pro-drop languages. A number of different proposals have been advanced by Hyams (1986, 1994, 1996), Valian (1991) and Rizzi (1994), among others. In this paper, I investigate the acquisition of subjects in two pro-drop languages, Spanish and Catalan, and argue in favor of an analysis within the Continuity Hypothesis. Briefly, in the area of the syntax of subjects, this hypothesis predicts an early convergence between child and adult grammars. 


\section{Aurora Bel}

In the Principles and Parameters framework, the pro-drop parameter has been defined as a cluster of properties (Rizzi 1982): 1) the possibility of null subjects, 2) the occurrence of postverbal subjects, 3) the lack of that-trace effect, and 4) the lack of overt expletive pronouns. In this paper, I investigate the former two properties in connection with the acquisition of this parameter. The analysis is extended to other phenomena, such as pronominal subjects, and other languages, such as English, and confirms the above mentioned convergence predicted by the continuity hypothesis.

In the first section, an overview of previous theories of the acquisition of subjects is presented in order to construct the hypothesis of this paper. In Section 2, I offer the overall results of children's subject use in Spanish and Catalan and compare them with those of child English. In Sections 3 and 4, I discuss the link between null subjects and verbal inflection; some restrictions in the cooccurrence of subjects and non-finite verb forms are discovered, but not with finite forms. In Section 5, I review the development of pronominal subjects; different conclusions are reached for null and overt subject languages. Section 6 is devoted to the analysis of subject position in the light of different verb types (unaccusative, transitive, etc.); we show that the behavior of children in this domain is adultlike. In the conclusions section, this series of facts allows us to argue against the absence of functional projections in early grammars and favors a full-specified set of projections except for non-finite constructions.

\section{The status of null subjects in the previous literature}

It is well known that, in the Principles and Parameters framework, a null subject parameter has been formulated. This parameter divides languages into two groups: languages that allow null subjects (pro-drop languages) and languages that do not allow them (non pro-drop languages). Regardless of the language they are acquiring, it is observed in the literature that children around the age of two years learning non pro-drop languages like English (Hyams 1986), French (Pierce 1992) or German (Hammann 1994) actually use null subjects. This is shown in the following examples:

$$
\begin{aligned}
& \text { a. Can make tail. } \\
& \text { b. Veux monter. } \\
& \text { want to climb } \\
& \text { c. bin wieder lieb. } \\
& \text { am again good }
\end{aligned}
$$

(Elena, 2;10)

Within the Continuity Hypothesis and according to Hyams (1986), children would begin with a default option, or unmarked option: their initial grammar (IG) would contain a pro category, the category for null subjects in languages 
like adult Italian or Spanish. This proposal implies that children learning non pro-drop languages would reset the parameter thus creating a learnability problem.

The idea of early convergence of child and adult grammar was proposed by Valian (1991). This author also noted that children's null subjects in English did not have the same properties as adults' null subjects in pro-drop languages: they are not found in $w h$-questions or in subordinate clauses. Another important observation from Valian (1991) concerns the systematic association between the child's omission of subjects and the behavior of pronominal subjects. Valian observed that for English-speaking children the decrease in the number of null subjects coincides with the increase in the number of pronominal subjects, lexical subjects remaining almost constant. On the other hand, based on Italian child data, she argues that a similar inverse relationship does not exist in this language. The consequence of these observations is that the initial null subject of languages like English cannot be pro, the null category for null subjects in pro-drop languages.

An alternative analysis of the early English pro-drop phenomenon is found in Hyams $(1992,1994)$. In these works, the author postulates that the null subject of English is pro, but a pro in topic position being accessible to identification via discourse topic by a topic chain. In this sense, early English is like German, a language that allows a null topic:

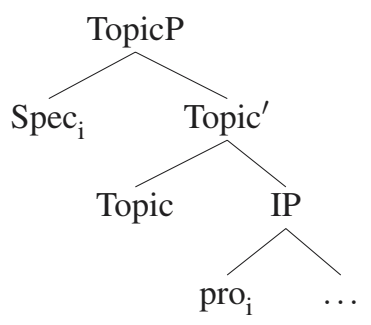

This analysis also allows overt subjects in early English in [Spec, IP] position. In Spanish and Catalan, null and (preverbal) overt subjects will occupy this position, i.e., [Spec, IP].

Nevertheless, the proposal of Hyams $(1992,1994)$ does not address the question of finiteness, i.e., whether there are differences in the behavior of subjects between finite and non-finite constructions. The prediction that it makes is that, in early stages, null and overt subjects will be attested regardless of finiteness (see Table 1). This is a problematic aspect that will be debated in the light of the acquisitional data of this paper.

Another formulation is that of Rizzi (1994), who proposes that the early null subject is a null constant $(n c)$, which is a category that has the property [-pronominal, -anaphoric, - variable]. Languages such as Chinese have this 
kind of category. Its identification and its formal licensing are done directly from discourse. However, this is possible because this category occupies the highest position in the phrase structure. Rizzi's Truncation Hypothesis establishes that child structures can be truncated under the $\mathrm{CP}$ level. Depending on the point in which the structural hierarchy is truncated, a different result will arise. If the hierarchy is truncated at the TP level, a root infinitive will arise. If the hierarchy is truncated at the level of AgrP, the result will be a subject root clause.

Let us turn to Spanish and Catalan. For these languages, it is proposed that the hierarchical sequence of functional and non-functional categories is that of (3), where the category IP is divided into its components, that is to say AgrP and TP:

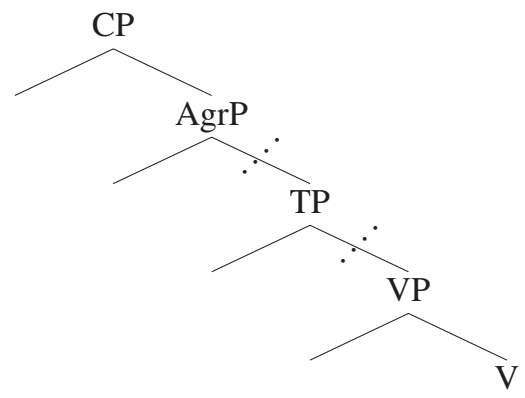

The dotted line indicates the place where the structure can be truncated. If truncation is done below TP, the structure emerges as a root infinitive (RI). If the structure is truncated above TP, the verb can be realized in its finite form and the structure projects a position that holds the grammatical subject. In both cases, the null category occupies the highest position of the configuration, being accessible to identification via discourse.

This framework predicts that the distribution of subjects varies depending on finiteness. In non-finite constructions, where TP is not projected, there is not place for a DP subject to check its features (phi-features and EPP); in this case, according to Rizzi (1994) the empty subject will be a null constant category. On the other hand, in finite constructions the projected TP category produces a configuration in which feature checking can occur between the $\mathrm{T}$ head and the (overt or null) DP subject in its Specifier position. So, the prediction is, as summarized in Table 1, that overt subjects will not occur with non-finite verbs whereas it is possible for a subject to co-occur with a finite verb. Moreover, a null subject is licensed in a finite construction.

Sano and Hyams (1994) and Hyams (1996) argue that in the early grammar of English I (or T) is underspecified, allowing a legitimate context for PRO. They, therefore, assume that the null subject of early English is PRO, an 
Table 1. Different analyses of null subjects in the initial grammar (IG)

\begin{tabular}{lllcc}
\hline Author(s) & $\begin{array}{l}\text { Null subject } \\
\text { category }\end{array}$ & Prediction & $\begin{array}{c}\text { Subjects with } \\
\text { finite verbs }\end{array}$ & $\begin{array}{c}\text { Subjects with } \\
\text { non-finite verbs }\end{array}$ \\
\hline $\begin{array}{l}\text { Hyams (1992, } \\
\text { 1994) }\end{array}$ & pro & $\begin{array}{l}\text { The IG has null } \\
\text { and overt } \\
\text { subjects } \\
\text { The IG has null } \\
\text { and overt } \\
\text { Rizzi (1994) }\end{array}$ & $+\quad+-$ & $?$ \\
null constant & + & - \\
$\begin{array}{l}\text { Grinstead } \\
(1998,2000)\end{array}$ & PRO IG does not & - & - \\
& & $\begin{array}{l}\text { have overt } \\
\text { subjects, only } \\
\text { null ones }\end{array}$ & & \\
\hline
\end{tabular}

$+=$ overt subject; $-=$ null subject

empty category proposed in the literature in order to account for subjects in non-finite clauses. Grinstead $(1998,2000)$ extends this proposal to the acquisition of Spanish and Catalan arguing that the initial grammar does not have a $\mathrm{T}$ projection responsible for licensing overt subjects. Consequently, overt subjects will not be attested, neither in finite constructions nor in non-finite constructions (see Table 1). Note that, in this proposal, early sentences are analyzed as non-finite. According to his proposal, Grinstead does not find instances of overt subjects in what he calls the first stage in the acquisition of Spanish and Catalan (up to two years, approximately). As will be shown, this is not the case with the data of the present research.

The different predictions that these hypotheses make about the behavior of subjects in finite and non-finite contexts are summarized in Table 1. In this paper, I will investigate to what extent these three hypotheses account for the data of the acquisition of Spanish and Catalan.

The hypothesis that I will try to defend in the present paper is conceived within the framework of the Continuity Hypothesis. According to this hypothesis and to the proposal that there is not resetting, early convergence is expected (Valian 1991). This proposal is close to the idea of very early parameter setting (VEPS) from Wexler (1996). Wexler proposes that, with the first multiple-word utterances, children have correctly set the basic parameters related to inflection. One of these parameters is the pro-drop parameter. Consequently, the working hypothesis can be formulated as follows:

(4) Spanish and Catalan children set the positive value of the pro-drop parameter early. 
In minimalist terms, this hypothesis implies that children know that $\mathrm{T}$ has an uninterpretable EPP feature which allows a null or overt DP subject to occupy the specifier position of $\mathrm{T}$, that is, [Spec, TP]. ${ }^{1}$ The consequence is that the early grammar should project such a category, at least for finite constructions. This hypothesis leads to the following predictions, which will be checked against the longitudinal data of acquisition of these two languages:

a. Null and overt subjects will be attested from the first productions, according to the respective adult grammars.

b. Preverbal and postverbal subjects will be documented early.

c. Overt pronominal subjects will not experience a significant increase throughout the development, as pointed in Valian (1991) for a pro-drop language like Italian.

For comparison with the acquisition of English, I will use the data of English acquisition from Valian (1991) as well as Austin et al. (1996).

\section{Corpora and general results}

The study of child language carried out in this paper is based on the analysis of longitudinal production data samples of six children monolingual in either Spanish or Catalan (see Table 2). Recording sessions took place twice a month over a twelve-month period. The samples consist of video recordings of spontaneous conversations of children aged between 1;7 and 2;6. The Catalan data are drawn from two different sources: the data from two of the subjects are from the Serra-Solé corpus (CHILDES database), whereas the data from the remaining subject come from a personal database discussed in Bel (1998). Finally, the Spanish children's data come from three different corpora: LópezOrnat (1994), Vila (1984) and Linaza corpus (CHILDES database). Transcriptions and coding follow the principles of the CHILDES system (MacWhinney, 1995).

To measure the co-occurrence of subjects and verbs, I extracted all child utterances containing one verb (finite or non-finite), i.e., sentential productions, using the CLAN Combo program developed for the CHILDES project (MacWhinney 1995). The results are presented in Table 3, where uses of null and overt subjects in the children's sentences are indicated separately. Note the parallelism between languages and also among the different children. The most outstanding fact of this table is the coincidence of total percentages of

\footnotetext{
1. Note that in (3) the structure has an AgrP projection. This proposal is previous to Chomsky (1995), who proposes a T projection that contains a T feature, which expresses the sentential tense, a set of phi-features, and an EPP feature.
} 
Table 2. Children and ages

\begin{tabular}{lllcl}
\hline Language & Child & Period & Number of sessions & Source \\
\hline Spanish & María & $1 ; 7-2: 6$ & 12 & López Ornat (1994) \\
& Emilio & $1 ; 10-2 ; 6$ & 10 & Vila (1984) \\
& Juan & $1 ; 9-2 ; 8$ & 8 & Linaza (CHILDES) \\
Catalan & Júlia & $1 ; 9-2 ; 6$ & 13 & Bel (1998) \\
& Pep & $1 ; 6-2,6$ & 11 & Serra-Solé (CHILDES) \\
& Gisela & $1 ; 10-2 ; 8$ & 6 & Serra-Solé (CHILDES) \\
\hline
\end{tabular}

Table 3. Null and overt subjects

\begin{tabular}{|c|c|c|c|c|c|c|}
\hline \multirow[t]{2}{*}{ Language } & \multirow[t]{2}{*}{ Child } & \multicolumn{2}{|c|}{ Null subjects } & \multicolumn{2}{|c|}{ Overt subjects } & \multirow[t]{2}{*}{ Total sentences } \\
\hline & & $\mathrm{n}$ & $\%$ & $\mathrm{n}$ & $\%$ & \\
\hline \multirow[t]{4}{*}{ Spanish } & María & 1027 & $(66.4 \%)$ & 518 & $(33.6 \%)$ & 1545 \\
\hline & Emilio & 484 & $(72.1 \%)$ & 187 & $(27.9 \%)$ & 671 \\
\hline & Juan & 119 & $(58.3 \%)$ & 85 & $(41.7 \%)$ & 204 \\
\hline & Total & 1630 & $(67.3 \%)$ & 790 & $(32.7 \%)$ & 2420 \\
\hline \multirow[t]{4}{*}{ Catalan } & Gisela & 337 & $(68.5 \%)$ & 153 & $(31.5 \%)$ & 492 \\
\hline & Júlia & 255 & $(67.3 \%)$ & 124 & $(32.7 \%)$ & 379 \\
\hline & Pep & 576 & $(67.5 \%)$ & 277 & $(32.5 \%)$ & 853 \\
\hline & Total & 1168 & $(67.7 \%)$ & 556 & $(32.3 \%)$ & 1724 \\
\hline
\end{tabular}

null subjects in Catalan and Spanish, superior to $67 \%$. A great coincidence between the Catalan children and María is observed (around $67 \%$ ), whereas the other two Spanish children, Emilio and Juan, diverge from the average.

The high percentage of null subjects is what we expect because in these two languages the absence of pronominal subject is associated with neutrality or lack of emphasis and, therefore, is the most frequent option in Spanish (Luján 1999) and also in Catalan. The presence of the pronominal subject in these languages denotes contrast. ${ }^{2}$ Table 4 shows some results in adult language.

Comparing the values between child and adult language (Tables 3 and 4), we do not observe great differences. This fact seems to indicate that children do not show a very different behavior from adults in this aspect.

However, treating data globally (Table 3) could hide some interesting trends in the first period of the syntactic development. In order to ascertain if this

2. According to Luján (1999: 1277), when a subject pronoun is overt in a context where the natural option is the omission, its function is contrastive or emphatic: Prometió que ella vendría a la reunión ('She promises that she would come to the meeting', the meaning being that "she" and nobody else would come to the meeting). 
Table 4. Null Subjects in adult spontaneous speech in Spanish and Catalan

\begin{tabular}{llll}
\hline Spanish & Silva-Corvalán & $(1977)$ & $61 \%$ \\
& Bentivoglio & $(1987)$ & $80 \%$ \\
& Enríquez & $(1984)^{\mathrm{a}}$ & $75 \%$ \\
\multirow{2}{*}{ Catalan } & Casanovas & $(1999)$ & $62 \%$ \\
\hline
\end{tabular}

a Use of the pronominal subject, without anaphoric uses $=25 \%$

is the case, a developmental study has been carried out. Every file of María's and Júlia's, each of them belonging to one of the target languages, has been analyzed. ${ }^{3}$ The results of this analysis (see Table 5) are surprising, and not because they do not follow a clear development, but because this development goes in opposite directions. So, whereas in the first file Júlia uses few overt subjects (only one overt subject out of 14 possible contexts, which represents a $92.8 \%$ of null subjects), María uses a $26.1 \%$ of null subjects and a $73.9 \%$ of overt subjects (in the first file, of the 46 possible contexts, the girl uses the lexical subject in 34 cases).

Moreover, a parallel increase between the number of overt subjects and the gradual growth of the average length of the utterance is not observed. Comparing the values of the last two columns of Table 5, a constant increase of overt subjects is not observed as the MLUw increases, calculated in number of words by sentence. ${ }^{4}$

In sum, these results suggest that the proportion of null and overt subjects is not a direct function of the length of the utterance (MLUw). It is not confirmed that the more words are used in an utterance (and, therefore, the more slots there are) the more easily the utterance will contain a subject.

The proportion of null subjects in adult Spanish and Catalan is situated between $60 \%$ and $80 \%$ (see Table 4). If the evolution of both girls is observed, we notice that they reach the percentage value that one could consider adult at the age of 2;2 (Júlia) and 1;10 (María). Precisely at this period, both girls reach an MLUw value of about two. However, we do not observe a radical change in their use of subjects at this stage. In the previous period the two girls use null

3. In what follows, when a detailed analysis of every file is needed, I will take two case studies, one for each language. Júlia's and María's are the largest corpus for each language. Moreover, these two girls have the highest sentence/utterance ratio.

4. The MLU value has been calculated as a ratio of words by sentence (MLUw), as proposed in the literature for Spanish (Aguado 1988). This author found that the MLU in terms of morphemes correlates with the MLUw at.99 for Spanish. The purpose of the MLU calculation in this paper is not to calculate the degree of syntactic complexity. The idea is that it is more likely to have a subject in a two-word sentence than in a one-word sentence. 
Table 5. Null subjects by ages (percentages)

\begin{tabular}{|c|c|c|c|c|}
\hline \multirow[t]{2}{*}{ Child Language } & \multirow[t]{2}{*}{ Age } & \multicolumn{2}{|c|}{ Null subjects } & \multirow[t]{2}{*}{ MLU } \\
\hline & & $\mathrm{N}$ & $\%$ & \\
\hline María & $1 ; 7$ & 12 & 26.1 & 1.854 \\
\hline \multirow[t]{11}{*}{ (Spanish) } & $1: 8$ & 7 & 30.4 & 1.958 \\
\hline & $1 ; 9$ & 30 & 53.6 & 2.018 \\
\hline & $1 ; 10$ & 52 & 74.3 & 1.990 \\
\hline & $1 ; 11$ & 45 & 70.3 & 2.020 \\
\hline & $2 ; 0$ & 94 & 72.8 & 2.438 \\
\hline & $2 ; 1$ & 122 & 65.6 & 2.442 \\
\hline & $2 ; 2$ & 151 & 78.6 & 2.753 \\
\hline & $2 ; 3$ & 161 & 72.8 & 3.590 \\
\hline & $2 ; 4$ & 90 & 73.7 & 3.383 \\
\hline & $2 ; 5$ & 130 & 66.3 & 4.282 \\
\hline & $2 ; 6$ & 133 & 55.4 & 3.940 \\
\hline Júlia & $1 ; 11.23$ & 13 & 92.8 & 1.459 \\
\hline \multirow[t]{9}{*}{ (Catalan) } & $2 ; 0.13$ & 13 & 86.6 & 1.633 \\
\hline & $2 ; 0.26$ & 9 & 81.8 & 1.837 \\
\hline & $2 ; 1.11$ & 24 & 48 & 1.942 \\
\hline & $2 ; 1.25$ & 12 & 44.4 & 1.802 \\
\hline & $2 ; 2.11$ & 25 & 73.5 & 1.805 \\
\hline & $2 ; 3.10$ & 26 & 65 & 2.071 \\
\hline & $2 ; 4.8$ & 33 & 64.7 & 2.447 \\
\hline & $2 ; 5.8$ & 46 & 71.8 & 2.373 \\
\hline & $2 ; 6.25$ & 35 & 64.8 & 2.819 \\
\hline
\end{tabular}

as well as overt subjects and in different proportions: María starts with a high proportion of overt subjects whereas Júlia starts with a high proportion of null subjects.

As a first conclusion, we have seen how Spanish and Catalan children show an early knowledge of the pro-drop option in accordance with their languages and alternate null and overt subjects, in different proportions, from the first files. This observation constitutes empirical proof against the predictions derived from the research by Grinstead $(1998,2000)$, who formulates the existence of a first period characterized by the total absence of overt subjects around the age of two.

In addition, one may wonder whether the English-speaking children show a similar knowledge. I will take the work of Austin et al. (1996) for comparison. 
Table 6. Null subjects in early English (from Austin et al. 1996)

\begin{tabular}{lcc}
\hline Age & MLU & Null subjects (percentage) \\
\hline $2 ; 0.2$ & 1.76 & 33.3 \\
$2 ; 6.18$ & 2.87 & 15 \\
\hline
\end{tabular}

The data of these authors for 9 children aged between 2;0.2 and 2;6.18 and with a MLU range from 1.76 to 2.87, are shown in Table 6.

The most interesting findings of this research are summarized as follow (Austin et al. 1996: 90):

1. The proportion of null subjects is always quite low (at most $33.3 \%$ ); it is worth remembering that in English there are contexts in which the null subjects are acceptable (mainly question-answer contexts). At the age of two years and a half children reach the adult percentage of null subjects (about $15 \%)$.

2. This proportion does not change drastically over the development. There is not an abrupt point of inflection, as one might expect in a hypothesis that appeals either to a resetting in the parameter or to the sudden grow of functional categories.

3. The proportion never reduces to zero, as in the adult language.

Consequently, the authors conclude that what is altered is not the grammatical knowledge but the pragmatic knowledge, since the correct use of a null subject depends on the interaction between grammar and pragmatics. In addition, the overall percentage of null subjects in child English is always lower than in child Spanish or Catalan.

These ideas lead to another brief research about the discursive contexts in which null subjects are used in a licit way, where licit means adultlike, or pragmatically felicitous.

\section{Subjects with finite verb forms}

In the previous section, it was shown that children use null and overt subjects in finite constructions. However, it could be that their use of subjects does not reflect adult usage, i.e., that illicit subjects are attested. In fact, according to the research by Austin et al. (1997), in child Spanish, as in child English, illicit uses of null subjects are attested, in a range of wrong uses that goes from an initial $68 \%$ to total disappearance. The range of ages are $1 ; 8$ to $2 ; 6$, approximately.

However, these results are not corroborated in the data of the present paper. Let us first observe some examples of the use of null subjects: 
The syntax of subjects in the acquisition of Spanish and Catalan

(6)

Spanish

a. MOT: Que se ha caído, estaba aquí puesto y se ha caído.

'It has fallen, it was here and it has fallen.'

CHI: (Es)tá aquí. [\% signalling the telephone] (María, 1;8)

is here

'It is here.'

b. CHI: $O$ loto.

(María, 1;9)

has broken

[\% 'se ha roto'; showing a broken pair of glasses]

'It has broken.'

c. CHI: Se cai [\% 'cae'; building a tower]. (María, 1;10)

CL falls

'It falls.'

(7)

Catalan

a. ADU: Que cau. [\% a toy tower is about to fall].

that(cj.) falls

'It falls.'

CHI: Ai, ai, cau!

(Gisela; $1 ; 8 b)$

ei, ei, falls

[\% screaming; the tower falls]

'It falls.'

b. CHI: Mira, (es)tà aquí.

look, is here

[\% grabbing theTV command]

'Look, it is here.'

c. CHI: Ui, punxa.

uy, tickles

[\% touching the horn of a snail]

'Uy, it tickles.'

These examples show some of the pragmatic conditions that regulate the use of null subjects. These conditions are not completely clear because in some examples the antecedent of the subject has not been mentioned in the previous speech acts, but its reference can be recovered easily because it is part of the knowledge of the state of affairs of both speaker and hearer or it is part of the physical environment. Nevertheless, this is true not only for child language, in which this effect is more frequent, but also for adult language (see, for example, the utterance of the mother in (6a) or the adult, in (7a)).

In synthesis, we have to be cautious when interpreting this kind of data, because conversational data are not the clearest data to distinguish licit and illicit null subjects. 


\section{Aurora Bel}

Let us go, now, to overt subjects. Inadequate uses are not detected, that is, an overuse of explicit subjects is not observed. ${ }^{5}$ Next are reproduced some typical overt subjects of early productions (subjects in italics):

(8)

Spanish

a. No está mariquita.

neg is ladybird

'Ladybird is not here.'

b. Cabeza, no está la cabeza. (Emilio, 2;0)

head, neg is the head

'The head is not here.'

c. Papá e(s) ma(lo). (María, 1;7)

Catalan

daddy is bad

(Emilio, 1;11)

a. Ja està el conte.

(Gisela, 2;1)

already is the tale

'The tale is finished.'

b. Aquesta altra seu a l' orinal. (Júlia, 2;1.11)

this other(one) sits at the chamberpot

c. $S$, ha t(r)encat la pilo(ta).

CL has broken the ball

'The ball has broken.'

(Pep, $1 ; 11)$

Briefly, at the pragmatic level the overt and implicit uses of subjects are quite similar in children and adults. In contrast, this is not confirmed for English: following Valian (1991) and Austin et al. (1996), in the majority of contexts where children use a null subject, adults use a pronoun. If, according to Austin et al. (1996), the trouble that children have in using null subjects is due to pragmatic knowledge, we can conclude that English-speaking children need more time to refine the conditions of tuning between grammatical and pragmatic knowledge.

\section{Subjects with non-finite verb forms}

The data up to now have concerned finite sentences. What about subjects in non-finite sentences? In previous work (Bel 1998, 2002), I defended that sentences with finite verbs are sentences that project a TP category responsible for

5. It is difficult to decide when a (null or overt) subject is pragmatically infelicitous, but it is possible to imagine some contexts with a wrong use of subject. For instance, in (6) the repetition of the subject would yield a wrong result: Que se ha caído el teléfono, el teléfono estaba ahí puesto y el teléfono se ha caído ('The telephone has fallen, the telephone was here and the telephone has fallen'). This kind of data is not attested at all in the children's production of this research. 
licensing the subject function. In languages with rich inflection such as Spanish and Catalan, the morphological endings of the verb are the way of licensing and interpreting subjects; they carry the information of number and person. Everything, then, signals to the existence of a narrow connection between subjects and verbal morphology.

A logical effect of this interaction is that the absence of verbal inflection has some consequences in the behavior of subjects. These consequences can be tested analyzing the occurrences of subjects with non-finite forms, particularly infinitives.

In previous work (Bel 1998, 2001) I adopted the Truncation Hypothesis (Rizzi, 1994) for children's root infinitives (RIs) and extended it to Spanish and Catalan and to all non-finite verb forms (infinitives, gerunds and participles). This analysis establishes that a given structure with a non-finite verb root is a truncated structure at the level of the TP (the doted line indicates the place where the structure is truncated):

$$
\begin{aligned}
& \text { Rizzi (1994): Truncation Hypothesis } \\
& {\left[_{\mathrm{CP}}\left[{ }_{\mathrm{AgrP}}\left[\mathrm{NegP}\left[\mathrm{TP} \quad \vdots\left[{ }_{\mathrm{VP}} \ldots \mathrm{V} \ldots\right]\right]\right]\right]\right.}
\end{aligned}
$$

This hypothesis suggests that, if AgrP and TP are not projected, we should not expect to find subjects with a non-finite root form. In effect, there are only 8 infinitives with subjects attested in the corpus (of the total 119 RIs) and no cases of gerunds or participles with an over subject. ${ }^{6}$ In Table 7 the contingency between the presence or absence of an overt subject and finiteness of verb forms (infinitive, gerunds and participles) in root constructions is significant $(\mathrm{p}<0.001){ }^{7}$

Root constructions demonstrate the close relation between the absence of verbal inflection of non-finite forms and the absence of overt grammatical sub-

6. For early Spanish, Liceras et al. (1999) also observe a clear preference for null subjects with RIs; in fact, one of their subjects (Magín) produces 17 null subjects out of 17 RIs and the other one (María) 53 out of 70. Some examples of the 8 exceptional RIs with subjects of the corpus of this research are the following:

(i) Spanish

Bibi [muñeco] dormi $(r)$.

(María, 1;8)

toy sleep-INF

(ii) Catalan

$$
\begin{array}{llll}
\text { A Júlia } & \text { se(u)re aquí. } \\
\text { the Júlia } & \text { sit-INF here }
\end{array}
$$

(Júlia, 2;2)

7. The data included in this table go from the first file of each child until the latest file in which a root non-finite verb form is attested. The latest file for each child is as follows: Emilio until 2;1.0, María until 2;1, Juan until 2;5, Gisela until 2;4.25, Júlia until 2;5.8 and Pep until 1;10.6. For a detailed discussion of this data, see Bel (2001). 
Table 7. Overt vs. null subjects in finite and non-finite root constructions of child Spanish and Catalan

\begin{tabular}{lcc}
\hline & Null subject & Overt subjects \\
\hline Finite constructions & 1317 & 512 \\
Root non-finite constructions & 181 & 8 \\
\hline
\end{tabular}

jects. These results confirm the correlation between verbal inflection (agreement and tense) and subjects in child language. Non-finite verbal units do not co-appear with overt subjects whereas finite verbal units do. This is an argument in favor of projecting TP (with tense and phi-features specified) in finite sentential structures.

\section{Subject pronouns}

As has been seen in Section 2, in Spanish and Catalan the presence of subject pronouns does not follow from the setting of the positive value of the pro-drop parameter. On the other hand, unlike Spanish and Catalan, in English the presence of pronominal subjects is due to grammatical requirements, i.e., the impossibility of omitting the subject, that characterizes a non pro-drop language. Consequently, in the case of English, the use of pronominal subjects derives from the negative value of the pro-drop parameter that characterizes this language, whereas, in Spanish and Catalan, strong pronouns play a pragmatic role. Valian (1994) derives a developmental prediction that should be right for English but not for Spanish or Catalan. This prediction appears in (5c) for Spanish and Catalan, formulated in the opposite way to the one formulated by Valian for English.

According to the pragmatic properties of subject pronouns, it has been suggested for Spanish as well for Catalan that pronominal subjects (strong pronouns) are not generated in the basic position but in a peripheral position attached to IP (Fernández Soriano 1989, Rigau 1988). ${ }^{8}$ One of the arguments for this proposal rests on the lack of parallelism with the empty pronominal category pro, characteristic of null subject languages as Spanish and Catalan.

In this section, I will investigate if a different developmental sequence is attested for English and for Spanish and Catalan. If strong pronouns play a pragmatic role in Spanish and Catalan, one may expect children to have to learn the

8. An anonymous reviewer points out that Kato (1999) also argues in favor of a peripheral position for subject pronouns but with a different analysis of IP. I would like to acknowledge this observation. 
contexts in which they must use them and, unlike English, a slow developmental increase is expected, as follows from prediction (5c). For English, on the other hand, if pronominal subjects depend on the non null subject option, then a developmental change is expected when children set the non pro-drop option of the parameter.

Let us start with English. In this language, the following was observed:

If one adds together the subjects that are absent and the subjects that are pronouns and divides by total number of subjects (absent plus pronominal plus lexical), that percentatge is roughly constant across the MLU range. [...] However, the percentage of pronouns out of the whole total increases dramatically [...] from $53 \%$ to $77 \%$. (Valian 1994: 277)

These data seem to indicate that in the early child English null and pronominal subjects are in complementary distribution. Moreover, according to the data in Austin et al. (1997), the proportions of pronominal subjects in early English and Spanish are significantly different:

Overt pronouns do not appear in the Spanish data until MLU 2.00, and never account for more than $40 \%$ of all subject types. In contrast, there is a very high proportion of lexical pronoun subjects in English even in the child with the lowest MLU (almost $60 \%$ ). (p. 44)

Let us turn to Spanish and Catalan. Previous works in Spanish (Ezeizabarrena 1996) highlight the scarcity or absence of subject pronouns in early production. The data derived from the corpus of the present work give the results of Tables 8 and 9.

The results in Tables 8 and 9 represent an overall use of strong pronouns of about $20 \%$; this result has to be reduced because it includes all uses of pronouns, not only subjects; there are instances of short answers with pronouns (¿Quién lo ha visto? Yo, 'Who have seen it? Me') or subjects with imperatives that play a different function (vocative) (Vine tu, 'Come, you'). If we compare this result (about a $12 \%$ of subject pronouns) with the adult use of subject pronouns (a $25 \%$ as indicated in Table 4), we verify a lower use in child language. This finding suggests that Spanish and Catalan children show difficulties in their knowledge of the pragmatic conditions for pronouns.

Briefly, after examining the literature on English, a clear and sudden increase of subject pronouns is observed whereas in Spanish and Catalan the developmental increase is slow. This fact supports the proposal that in the latter two languages the behavior of subject pronouns is not a property that derives from the pro-drop parameter. 
Table 8. Frequencies of strong pronouns in Spanish (up to 2;6)

\begin{tabular}{|c|c|c|c|c|}
\hline Child & Age & Yo ('I') & Tú ('You') & Él/Ella ('He/she') \\
\hline \multirow[t]{6}{*}{$\overline{\text { Emilio }}$} & $2,1 \mathrm{a}$ & & 1 & \\
\hline & $2,1 b$ & 4 & & \\
\hline & $2 ; 3$ & 7 & & \\
\hline & $2 ; 4$ & 2 & & \\
\hline & $2 ; 5$ & 3 & & \\
\hline & $2 ; 6$ & 4 & & \\
\hline \multirow[t]{6}{*}{ Juan } & $2 ; 0$ & 1 & & \\
\hline & $2 ; 1$ & & & \\
\hline & $2 ; 3$ & 2 & 2 & \\
\hline & $2 ; 4$ & 24 & 17 & \\
\hline & $2 ; 5 a$ & 5 & 6 & \\
\hline & $2 ; 5 b$ & 2 & 20 & \\
\hline \multirow[t]{10}{*}{ María } & $1 ; 9$ & 2 & & \\
\hline & $1 ; 10$ & 7 & & \\
\hline & $1 ; 11$ & 2 & & \\
\hline & $2 ; 0$ & 9 & & \\
\hline & $2 ; 1$ & 30 & & \\
\hline & $2 ; 2$ & 13 & 1 & \\
\hline & $2 ; 3$ & 25 & 1 & \\
\hline & $2 ; 4$ & 9 & 1 & \\
\hline & $2 ; 5$ & 16 & & \\
\hline & $2 ; 6$ & 24 & 1 & \\
\hline Total & & 180 & 40 & \\
\hline
\end{tabular}

\section{The position of subjects}

One of the properties that has standardly been connected with the pro-drop parameter is the possibility of having subjects in postverbal position. For this reason, the hypothesis defended here predicts an early presence of preverbal and postverbal subjects (see the prediction (5b)).

In order to test this prediction, all overt subjects of Table 3 were counted and divided according to the relative position in relation with the verb. The results obtained are shown in Table 10. In fact, these results support the prediction that preverbal as well as postverbal subjects are attested in the data. 
Table 9. Frequencies of strong pronouns in Catalan (up to 2;6)

\begin{tabular}{llccc}
\hline Child & Age & Jo ('I') & $T u$ ('You') & Ell/Ella ('He/she') \\
\hline Gisela & $1 ; 10$ & 1 & & \\
& $2 ; 2$ & 10 & 2 & \\
& $2 ; 4$ & & 7 & \\
\multirow{3}{*}{ Júlia } & $2 ; 6$ & 11 & & \\
& $2 ; 5$ & 7 & 1 & \\
Pep & $2 ; 6$ & 4 & 1 & \\
& $1 ; 10$ & & 2 & \\
& $2 ; 2$ & & 1 & \\
& $2 ; 3$ & 1 & 1 & \\
& $2 ; 4$ & 14 & 1 & \\
Total & $2 ; 5$ & 9 & 7 & \\
\hline
\end{tabular}

Table 10. Frequencies and percentages of preverbal and postverbal subjects

\begin{tabular}{llrrrrrr}
\hline Language & Child & \multicolumn{2}{c}{$\begin{array}{c}\text { Preverbal } \\
\text { subjects }\end{array}$} & & \multicolumn{2}{c}{$\begin{array}{c}\text { Postverbal } \\
\text { subjects }\end{array}$} & \multirow{2}{*}{$\begin{array}{c}\text { Total overt } \\
\text { subjects }\end{array}$} \\
\cline { 3 - 4 } & & $\mathrm{N}$ & $\%$ & & $\mathrm{~N}$ & $\%$ & \\
\hline Catalan & Gisela & 118 & $(77.1)$ & & 37 & $(22.9)$ & 153 \\
& Júlia & 68 & $(69.3)$ & & 38 & $(30.7)$ & 124 \\
& Pep & 170 & $(61.3)$ & & 107 & $(38.7)$ & 277 \\
Total & & 374 & $(67.2)$ & & 182 & $(32.8)$ & 556 \\
Spanish & María & 313 & $(60.4)$ & & 205 & $(39.6)$ & 518 \\
& Emilio & 120 & $(64.1)$ & & 67 & $(35.9)$ & 187 \\
\multirow{2}{*}{ Total } & Juan & 52 & $(61.1)$ & & 33 & $(38.9)$ & 85 \\
& & 485 & $(61.3)$ & 305 & $(38.7)$ & 790 \\
\hline
\end{tabular}

Nevertheless, it is interesting to pay attention to an aspect derived from the existence of postverbal subjects in Spanish and Catalan. A constant is observed in Table 10: the proportion of preverbal subjects is higher, almost double, than that of postverbal subjects. If children are in tune with the adult speakers of their languages, as predicted in this paper following the Continuity Hypothesis, these results would indicate that Spanish and Catalan speaking children prefer 


\section{Aurora Bel}

the SVO order and that, perhaps, this is the basic order. Shortly we will see that this is not the case. I will suggest that there are other linguistic facts that cause this superficial order and that postverbal subjects are not a property directly and exclusively linked to the pro-drop parameter as has been standardly proposed.

Let us first reproduce some sentences from the same children with the same verbs but with different linear orders (examples from Catalan) (subjects in roman):

$$
\begin{aligned}
& \text { a. Aquest és molt maco. } \\
& \text { this is very nice } \\
& \text { b. On és Goofy? } \\
& \text { where is Goofy? }
\end{aligned}
$$

a. Aquí ha trobat (1)a Júlia.

(Júlia, 2;0.26) here has found the Júlia 'Júlia has found (it) here.'

b. (L)a Júlia no trobava. the Júlia neg found 'Júlia didn't found (it).' 'Mummy ran.'

b. (L)a mama colava. the mummy ran

'Mummy ran.'

(Júlia, 2;2.11)

a. Cau això, mama.

falls that mummy

'That falls, mummy.'

(Júlia, 2;1.11)

b. Això cau.

(Júlia, 2;1.11) that falls

The examples in (11) contain a stative verb, (12) a transitive verb, (13) an intransitive verb (also called unergative) and (14) an unaccusative verb (or ergative). In all the cases, the subject can appear before as well as after the verb, independently of the verb type. It is assumed that with unaccusative verbs the subject, which is generated in the position of the internal argument, normally appears in postverbal position. However, the intransitive and transitive verbs seem to favor the SV order.

According to the VP Internal Subject Hypothesis, as advanced in Koopman and Sportiche (1991), the external argument, i.e., the subject, is generated inside the VP. Assuming this hypothesis, several authors have suggested that languages such as Spanish or Catalan are better characterized as a VOS, rather 
than SVO (Fernández Soriano (1989), Contreras (1991) or Ordóñez and Treviño (1999), for Spanish; Rosselló (1986), Bonet (1990) or Solà (1992) for Catalan). Briefly, in these formulations postverbal subjects are in fact occupying their basic position whereas preverbal subjects are subjects dislocated to the left from their basic position. This proposal accounts for the high proportion of postverbal subjects in the adult language.

The phenomenon of subject inversion in Spanish and Catalan is more complex than it seems at first sight. It is due to different factors, among which are the possibilities of dislocation according to the information structure of the utterances and the type of verb. In a neutral construction, when a subject is interpreted as new information, it occupies a position to the right of the verb, yielding $\mathrm{V}(\mathrm{O}) \mathrm{S}$ order. ${ }^{9}$ On the other hand, when the subject receives contrastive focus, it is realized in the FocusP of the C-field (Rizzi 1997) leading SV(O) order as is shown in the configuration in (15):

(15)

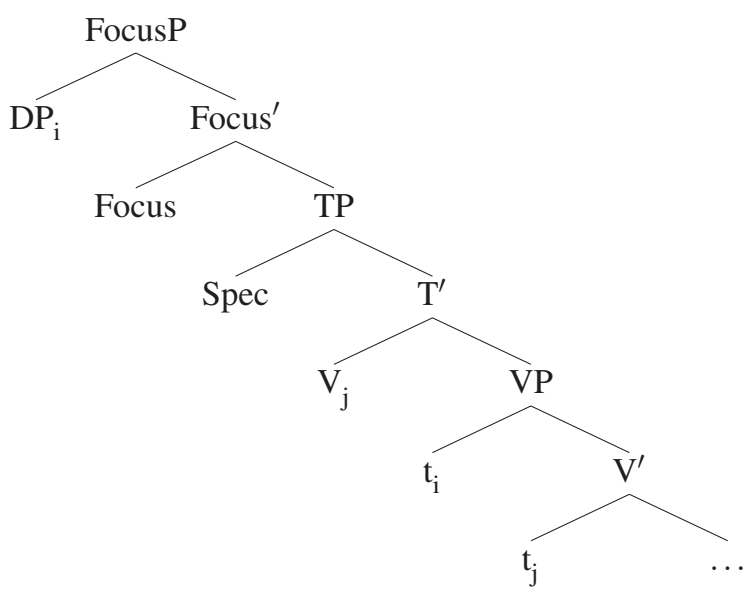

Moreover, as has been advanced, the type of verb is also relevant for the position of subjects. In concrete, it has been argued in the literature that unaccusative verbs lack a true external argument, the superficial subject being the internal argument. Then, the prediction is that it will be easier to find the subject in the postverbal position being like an internal argument.

Having noticed that there are different factors that determine subject position, the proposal that I would like to defend in the next pages is that, if we take into consideration all these factors together, we cannot continue to maintain that postverbal subjects derive (only) from the pro-drop parameter.

9. There are different manners of deriving V(O)S. For example, Ordónez and Treviño (1999) propose that subjects move to a NeutralP, between TP and VP. 
Table 11. Subject position according to the type of the verb. Absolute frequencies. Júlia (Catalan)

\begin{tabular}{|c|c|c|c|c|c|c|c|c|}
\hline \multirow[t]{2}{*}{ Age } & \multicolumn{2}{|c|}{ Stative } & \multicolumn{2}{|c|}{ Transitive } & \multicolumn{2}{|c|}{ Intransitive } & \multicolumn{2}{|c|}{ Unaccusative } \\
\hline & Prev. & Post. & Prev. & Post. & Prev. & Post. & Prev. & Post. \\
\hline $2 ; 0.13$ & & & 1 & & & & 2 & \\
\hline $2 ; 0.26$ & 1 & & & 1 & & & 3 & 5 \\
\hline $2 ; 1.11$ & 1 & & 4 & 2 & 2 & 3 & 2 & 4 \\
\hline $2 ; 1.25$ & 1 & & 5 & & 2 & 1 & & \\
\hline $2 ; 2.11$ & & & 4 & 1 & 4 & & 2 & 2 \\
\hline $2 ; 3.10$ & & & 1 & 5 & 3 & & 3 & 3 \\
\hline $2 ; 4.8$ & 2 & & 4 & & 4 & & & 1 \\
\hline $2 ; 5.8$ & 6 & & 6 & & 2 & 1 & & \\
\hline $2 ; 6.25$ & 5 & 2 & 4 & & & 4 & 1 & \\
\hline Total & 16 & 2 & 29 & 9 & 17 & 9 & 13 & 15 \\
\hline
\end{tabular}

Following these ideas, a detailed analysis is provided (see Note 3). I have carried out a count of all verbs produced by Júlia and the position of syntactic subjects throughout her development in order to find out whether unaccusative verbs present a different behavior (Table 11).

The data in Table 11 show quite a clear result. As a rule, preverbal subjects are more frequent than postverbal subjects and this happens with all types of verbs, except for unaccusative verbs. In this latter case the proportion is inverted and postverbal subjects reach a higher value. So, it does not seem to be by chance that this trend is observed, but rather because of the particularities of the subjects of unaccusative verbs. This fact does not necessarily mean that all subjects appear in postverbal position. A relation of examples of Júlia's will clarify the facts a little more. The examples in (16) belong to the canonical order of this type of verb whereas (17) shows preverbal subjects:

(16) Unaccusative verbs: Postverbal subjects

a. (S')ha trencat e(l) cap [\% pap].

CL has broken the head

'His head has broken.'

b. Només es va trencar l' enanito.

only CL broke the little dwarf

'Only the little dwarf broke.'

c. Pica la panxa.

itches the tummy

'My tummy itches.' 
a. MOT: Com la posaràs, la nina?

'How are you going to put the doll?'

CHI: AIXÒ ha caigut.

that has fallen

FAD: I a veure aquest?

'And what about this one?'

CHI: No, aquest no ( $\left.s^{\prime}\right)$ aguanta.

neg, this neg CL stands

'No, this does not stand.'

b. MOT: Què esteu fent per (a) la mama?

'What are you doing for mummy?'

CHI: AIXÒ no es munta.

this neg CL fits

'This doesn't fit.'

These examples can be explained by using the distribution between new and known information. In Catalan, in the utterances in which everything is new information the subject appears in its basic position, that is, after the verb; it is the case of the examples in (16). However, when the subject appears in first position, it is due to several factors. The known information has two possible positions, both dislocated: "left-detached phrases are links, while rightdetached ground phrases are tails."(Vallduví and Engdahl 1996: 479). In (17b) the dislocated subject acts as a link between the two adjacent utterances. In $(17 \mathrm{a}, \mathrm{c})$, the dislocated subjects occupy a focus position: the focalized element is a highlighted element. It is a definite element (a deictic in this case), unlike new information, which is usually indefinite. In other words: when in an unaccusative construction there are not discursive reasons (informational structure) that justify a left-detached position, the subject appears in situ, i.e. after the verb (examples of (16)). When the informational structure requires a marked order, the subject appears dislocated, normally to the left, according to the possibilities of the language.

Table 12 illustrates the results of the subject position in relation with the verb type for María. In order to get an idea of the distribution of subjects in María's corpus, only the first six files, up to 2;0, have been calculated. In the column of postverbal subjects with stative verbs, the cases of obligatory inversion of the subject (between parenthesis) have been subtracted, that is, the interrogatives utterances of the type Ostáx? ('Where is x?'), so usual in María's talk. Therefore, the number in the box Total is the result of adding the postverbal subjects and subtracting the obligatory ones.

Some examples of subjects with unaccusative verbs of María will clarify us more these data: 


\section{Aurora Bel}

Table 12. Subject position according to the type of the verb. Absolute frequencies. María (Spanish)

\begin{tabular}{|c|c|c|c|c|c|c|c|c|}
\hline \multirow[t]{2}{*}{ Age } & \multicolumn{2}{|c|}{ Stative } & \multicolumn{2}{|c|}{ Transitive } & \multicolumn{2}{|c|}{ Intransitive } & \multicolumn{2}{|c|}{ Unaccusative } \\
\hline & Prev. & Post. & Prev. & Post. & Prev. & Post. & Prev. & Post. \\
\hline $1 ; 7$ & 11 & $14(-5)$ & & & & & & 5 \\
\hline $1 ; 8$ & 3 & $7(-4)$ & 1 & & & 1 & 2 & \\
\hline $1 ; 9$ & 1 & $8(-6)$ & & & 3 & & 2 & 4 \\
\hline $1 ; 10$ & 4 & 3 & & 3 & 1 & & 2 & 3 \\
\hline $1 ; 11$ & 2 & 1 & & 1 & & 1 & 4 & 12 \\
\hline $2 ; 0$ & 8 & 2 & 10 & 4 & 4 & 1 & 6 & 3 \\
\hline Total & 29 & 20 & 11 & 8 & 8 & 3 & 16 & 27 \\
\hline
\end{tabular}

(18) Unaccusative verbs: Postverbal subjects
a. Se cae e(l) nene.
CL falls the baby
'The baby falls.'
b. Fa(l)ta el ot(r)o pendiente. misses the other earring
'The other earring is missing.'
c. ¡Ah! No (se) para (e)se patito. ah! neg CL stops that little duck 'That little duck doesn't stop.'

\section{Unaccusative verbs: Preverbal subjects}
a. Este se quita [\% cae].
this CL removes
'It falls.'
b. GUAUGUAU no pasa. Dog do not pass
c. ¿Sabes? Se rompe, e(s)te patito se rompe. $(2 ; 0)$ You know? CL breaks, this little duck CL breaks 'You know? It breaks, this little duck breaks.'

As with Júlia's utterances (17a, c), the deictic este ('this') in (19a, c) receives contrastive focus and, therefore, occupies a peripheral position. In the same way, in (19b), guauguau has a focus reading although it is also new information (in English it would receive pitch accent, as caps indicate) whereas no pasa ('do not pass') is known information. This causes the subject to occupy a preverbal position. 
After discussing this set of data, one can conclude that a high frequency of postverbal subjects in the data of child production is not a demonstration of children's knowledge of the setting of the pro-drop parameter. Rather the results suggest that children know the unaccusative verb frame. Consequently, it seems that children are able to extract regularities from the data in order to figure out different verb types with different frames. These verb types are of a lexical nature. In addition, there are pragmatic factors (information structure) that determine the position of the subject and, according to the data in the previous pages, it appears that children know this set of factors (or a subset of them). Moreover, this is true for the rest of verb types as the examples in (11)-(14) show.

The data discussed in this section lead us to postulate a focus feature that enables children to project the corresponding category in order to account for the attested orders. Thus the child grammar must have a projection such as Focus Phrase, capable of hosting focalized elements. In synthesis: despite accepting that the basic order in Spanish and Catalan is VOS, there are different reasons that cause the subject to appear in a position preceding the verb. These causes have a pragmatic-informative origin and are found in conversational contexts. In the present paper, the corpus with which we are working is of this nature, which could explain the general results of Table 10, according to which there is a wide majority of preverbal subjects. However, with unaccusative verbs the results are the opposite. It does not seem logical to suppose that the causes that we have called pragmatic-informative apply more in a given verb type than in another. Consequently, on the assumption that pragmatic restrictions apply equally to all verb types, the data about unaccusative verbs in Tables 11 and 12 should be interpreted as reflecting the knowledge of the properties of this verb type by children. This is an important aspect of the syntax of subjects on which Spanish and Catalan children seem to converge early on.

\section{Conclusions}

After analyzing the use of subjects in the acquisition of Spanish and Catalan in the corpus and comparing it with English, we reach the following conclusions:

1. Children that acquire Spanish and Catalan know early that their languages are null subject languages, and alternate null and overt subjects from the very beginning. This confirms the prediction in (5a) and goes against the prediction derived from work by Grinstead $(1998,2000)$.

2. After examining English, we found that there is a lower proportion of null subjects in early English than in Spanish and Catalan, in tune with the adult language. This provides support for what has been called early convergence 
between the initial grammar and the adult grammar (Valian 1991) and seems to confirm the hypothesis formulated in (4).

3. A high correlation is observed between subjects (null or overt) and verbal inflection (finite or non-finite). This goes against Hyams (1992, 1994), who does not address the differences derived from finiteness. The data about finiteness allow us to adopt the truncation proposal of Rizzi (1994) with a null constant $(n c)$ representing the null subject for root non-finite constructions. In contrast, in finite constructions I have proposed that a TP category is projected yielding a structure in which the (null or overt) subject can be realized. In this configuration, pro is licensed, yielding null subjects as in adult grammars. Briefly, Spanish and Catalan children project $\mathrm{T}$ in their early grammars, but also truncated structures.

4. In English, where pronominal subjects satisfy a grammatical requirement, the use of pronouns in subject position grows quickly and suddenly, whereas in languages like Spanish or Catalan subject pronouns do not experience such sudden growth, in agreement with the findings in Valian (1991), thus confirming the prediction in $(5 \mathrm{c})$.

5. Finally, preverbal and postverbal subjects have been attested in the acquisition data of Spanish and Catalan as advanced in prediction (5b). Nevertheless, we have shown that the position of the subject does not derive only from the pro-drop parameter and that other categories located in the C-field are to be projected in order to account for the attested orders. This fact allows us to postulate an initial grammar (IG) with a fully specified set of projections except for root constructions.

Universitat Pompeu Fabra

\section{Acknowledgements}

I am very grateful to Jürgen M. Meisel for encouraging me to write this paper. I thank the anonymous reviewers for their helpful and relevant suggestions. Special thanks to Alex Alsina for his useful comments and for his help with English. Of course, all remaining errors are my own. The research reported in this paper was partially supported by the Ministerio de Ciencia y Tecnología (Spain), grant no. BFF2000-0928 and grant no. BFF2000-0504.

\section{References}

Aguado, Gerardo (1988). Appraisal of the morpho-syntactic competence in a 2;5 month old child. Infancia y Aprendizaje 43: 73-95. 
Austin, Jennifer, María Blume, Barbara Lust, Zelmira Núñez del Prado, David Parkinson and Reyna Proman (1996). Current challenges to the parameter-setting paradigm: The pro-drop parameter. In Proceedings of the Groningen Assembly on Language Acquisition held at the University of Groningen, 7-9 September 1995, C. Koster and F. Wijnen (eds.), 87-96. Groningen: Centre for Language and Cognition.

Austin, Jennifer, María Blume, David Parkinson, Zelmira Núñez del Prado and Barbara Lust (1997). The Status of Pro-Drop in the Initial State: Results from New Analyses of Spanish. In Contemporary Perspectives on the Acquisition of Spanish. Volume I: Developing Grammars, A.T. Pérez-Leroux and W.R. Glass (eds.), 37-54. Somerville, Mass.: Cascadilla Press.

Bel, Aurora (1998). Teoria lingüística i adquisició del llenguatge. Anàlisi comparada dels trets morfològics en català i en castellà. Ph.D. dissertation. Universitat Autònoma de Barcelona, Barcelona.

- (2001). The Projection of Aspect: A Key in the Acquisition of Finiteness? In Research on Child Language Acquisition. Proceedings of the 8th Conference of the International Association for the Study of Child Language, 1300-1316. Somerville/Massachusetts: Cascadilla Press.

- (2002). Early Verbs and the Acquisition of Tense Feature in Spanish and Catalan. In The Acquisition of Spanish Morphosyntax: the L1/L2 Connection, J.Muñoz Liceras and A.T. Pérez Leroux (eds.), 1-31. Dordrecht: Kluwer.

Bonet, Eulàlia (1990). Subjects in Catalan, MIT Working Papers in Linguistics 13: 1-26.

Bentivoglio, P. (1987). La posición del sujeto en el español de Caracas: Un análisis de los factores lingüísticos y extralingüísticos. In Studies in Caribbean Spanish Dialectology, R.M. Hammond and and M. Resnick (eds.), 13-23. Whashington: Georgetown University Press.

Casanovas, Lourdes (1999). El sujeto en el catalán coloquial. Revista Española de Lingüística 29,1: 105-131.

Chomsky, Noam (1995). The Minimalist Program. Cambridge, Mass.: The MIT Press.

Contreras, Heles (1991). On the Position of Subjects. In Syntax and Semantics. Volume 25. Perspectives on Phrase Structure: Heads and Licensing, S.D. Rothstein (ed.), 63-79. New York: Academic Press.

Enríquez, Emilia V. (1984). El pronombre personal sujeto en la lengua española hablada en Madrid. Madrid: Consejo Superior de Investigaciones Científicas.

Ezeizabarrena, María José (1996). Adquisición de la morfología verbal en euskera y castellano por niños bilingües, Vitoria: Servicio Editorial de la Universidad del País Vasco [Ph.D. dissertation, Hamburg University].

Fernández Soriano, Olga (1989). Strong Pronouns in null-subjects languages and the Avoid Pronoun Principle. MIT Working Papers in Linguistics 11: 228-239.

Grinstead, John (1998). Subjects, sentential negation and imperatives in child Spanish and Catalan. $\mathrm{Ph} . \mathrm{D}$. dissertation, UCLA, Los Angeles.

- (2000). Case, inflection and subject licensing in child Catalan and Spanish. Journal of Child Language 27: 119-155.

Hamann, Cornelia (1994). Null Arguments in German Child Language. Geneve Generative Papers 2 (2): 62-90.

Hyams Nina (1986). Language Acquisition and the Theory of Parameters. Dordrecht: Reidel.

- (1992). A Reanalysis of Null Subjects in Child Language. In Theoretical Issues in Language Acquisition. Continuity and Change in Development, J. Weissenborn, H. Goodluck, T. Roeper (eds.), 249-267. Hove-London: Lawrence Erlbaum.

- (1994). VP, Null Arguments and COMP Projections. In Language Acquisition Studies in Generative Grammar, T. Hoekstra and B.D. Schwartz (eds.), 21-55. Amsterdam: John Benjamins.

- (1996). The Underspecification of Functional Categories in Early Grammars. In Generative Perspectives on Language Acquisition. Empirical Findings, Theoretical Considerations and Crosslinguistic Comparisons, H. Clahsen (ed.), 91-127. Amsterdam: John Benjamins. 
Kato, Mary Aizawa (1999). Strong and weak pronominals in the null subject parameter. Probus 11: $1-37$.

Koopman, Hilda and Dominique Sportiche (1991) The Position of Subjects. Lingua 85: 211-258. Liceras, Juana M., Elena Valenzuela and Lourdes Díaz (1999). L1 and L2 developing Spanish grammars and the 'pragmatic deficit hypothesis'. Second Language Research 15,2: 161-190.

López Ornat, Susana (1994). La adquisición de la lengua española. Madrid: Siglo XXI.

Luján, Marta (1999). Expresión y omisión del pronombre personal. In Gramática Descriptiva de la Lengua Española, I. Bosque and V. Demonte (eds.), 1275-1316. Madrid: Espasa.

MacWhinney, Brian (1995). The CHILDES Project: Tool for Analizing Talk. Hillsdale, New Jersey: Lawrence Erlbaum.

Ordóñez, Francisco and Esthela Treviño (1999). Left dislocated subjects and the pro-drop parameter: a case study of Spanish. Lingua 107: 39-68.

Pierce, Amy E. (1992). Language Acquisition and Syntactic Theory. A Comparative Analysis of French and English Child Grammars. Dordrecht: Kluwer.

Rigau, Gemma (1988). Strong Pronouns. Linguistic Inquiry 19,3: 303-311.

Rizzi, Luigi (1982). Issues in Italian Syntax. Dordrecht: Foris.

- (1994). Early Null Subjects and Root Null Subjects. In Syntactic Theory and First Language Acquisition: Cross-Linguistic Perspectives. Vol. 2, B. Lust, G. Hermon and J. Kornfilt (eds.), 249-272. Hove-Londres: Lawrence Erlbaum

- (1997). The Fine Structure of Left Periphery. In Elements of Grammar, L. Haegeman (ed.), 281-337. Dordrecht: Kluwer.

Rosselló, Joana (1986). Gramàtica, configuracions i referència: per una teoria alternativa del pro-drop romànic. Ph.D. dissertation, Universitat de Barcelona, Barcelona.

Sano, Tetsuya and Nina Hyams (1994). Agreement, Finiteness, and the Development of Null Arguments. Proceedings of NELS 24: 543-558 (vol. 2).

Silva-Corvalán, Carmen (1977). A Discourse Study of Some Aspects of Word Order in the Spanish Spoken by Mexican-Americans in West Los Angeles. Ph.D. dissertation, UCLA, Los Angeles.

Solà, Jaume (1992). Agreement and subjects. Ph.D. dissertation, Universitat Autònoma de Barcelona, Barcelona.

Valian, Virginia (1991). Syntactic subjects in the early speech of American and Italian children. Cognition, 40: 21-82.

- (1994). Children's Postulation of Null Subjects: Parameter Setting and Language Acquisition. In Syntactic Theory and First Language Acquisition: Cross-Linguistic Perspectives. Vol. 2, B. Lust, G. Hermon and J. Kornfilt (eds.), 273-286. Hove-London: Lawrence Erlbaum.

Vallduví, Enric and Elisabet Engdahl (1996). The linguistic realization of informational packaging. Linguistics 34: 459-519.

Vila, Ignasi (1984). La competencia comunicativa en los dos primeros años de vida. Ph.D. dissertation, Universitat de Barcelona, Barcelona.

Wexler, Kenneth (1996). The Development of Inflection in a Biologically Based Theory of Language Acquisition. In Towards a Genetics of Language, M.L. Rice (ed.), 113-144. Mahwah, New Jersey: Lawrence Erlbaum. 